AQUATIC FLOW CYTOMETRY: ACHIEVEMENTS AND PROSPECTS. M. RECKERMANN and F. COLIJN (eds.)

\title{
Short-term variations of the vertical distribution of cyanobacteria in the open Mediterranean Sea *
}

\author{
MICHEL DENIS $^{1 *}$, VALÉRIE MARTIN ${ }^{1}$ and VALÉRIE ANDERSEN ${ }^{2}$ \\ 'Laboratoire d'Océanographie et de Biogéochimie, Université de la Méditerranée, CNRS UMR 6535, Parc Scientifique et \\ Technologique de Luminy, Case 901, 13288 Marseille cedex 9, France. \\ Fax: 334918265 48. E-mail: denis@com.univ-mrs.fr \\ ${ }^{2}$ Observatoire Océanologique, Station Zoologique, CNRS ESA 7076, BP 28, 06234 Villefranche-sur-Mer cedex, France
}

\begin{abstract}
SUMMARY: A general study of biogeochemical processes (DYNAPROC cruise, May 1995) was conducted at a station in the open northwestern Mediterranean Sea where horizontal advection was weak. During this experiment, short-term variations of the vertical distribution of cyanobacteria were investigated and a possible link with diel vertical migration was considered. Consistently, the experimental work was conducted at a time scale of a few hours. Cyanobacteria were the most abundant population in the pico- and nanoplankton size-class. Their vertical distribution was monitored over $36 \mathrm{~h}$ with a frequency of $4 \mathrm{~h}$. With such a time resolution, they experienced a single grazing event during daytime and, at night, they were heavily grazed when the upper layers were occupied by organisms migrating from the aphotic zone. The corresponding integrated $(0-90 \mathrm{~m})$ losses of cyanobacteria during the night amounted to $534 \mathrm{mg} \mathrm{C} \mathrm{m}^{-2}$. Though daytime grazing is most likely due to nanoflagellates and microzooplankton, night-time grazing could significantly involve migrant macrozooplankton organisms and sustain a periodic export of organic matter. This study stresses the importance of the potential export of organic matter as a consequence of the diel vertical migration, export that could not be accounted for by measurements at longer time scale.
\end{abstract}

Key words: cyanobacteria, Mediterranean Sea, flow cytometry, diel vertical migration.

\section{INTRODUCTION}

Export of organic matter from the euphotic zone to deeper waters has been of major concern for the oceanographic community for many years. This question gave rise to the concept of new and regenerated production (Dugdale and Goering, 1967) where new production was defined as organic matter derived from nitrate uptake by the autotroph phytoplankton whereas the regenerated production is derived from their ammonium uptake. This concept was expressed by Eppley and Peterson (1979) in

\footnotetext{
*Received May 3, 1999. Accepted February 14, 2000.
}

terms of the $f$ ratio (new production/(new + regenerated production)). In the early general understanding, the export of organic matter was assumed essentially to be in the particulate form. Since then, evidence has been provided for the transfer of dissolved organic matter (DOM) to the aphotic zone (CopinMontégut and Avril, 1993; Carlson et al., 1994). In addition, different studies documented the production of DOM in the euphotic zone (Smith et al., 1992) and its role in the upper layer where export of dissolved organic nitrogen has been shown to be up to two fold that of particulate organic nitrogen (Pujo-Pay, 1995). Diel vertical migrations (DVM) of zooplanktonic organisms are a common feature of 
temperate waters. They are supposed to play a significant role in the export of organic matter through sinking fæcal pellets and aggregates and in the redistribution of nitrogen throughout the nutricline (Angel, 1989 ; Longhurst and Harrison, 1989; Lampitt et al., 1993). However, the extent of their impact on the export of organic matter from the euphotic zone to deep waters is still unresolved. One piece of information can be obtained by quantifying grazed populations during the occupancy of the upper layer by the migrant organisms.

In the present work, one such attempt is made, focused on the cyanobacteria population in the northwestern Mediterranean Sea. This study was part of a more general investigation of biogeochemical processes (DYNAPROC cruise, May 1995). This cruise focused on the functioning of the biological pump (Longhurst and Harrison, 1989; Bishop, 1989) and was conducted mainly at a time series station where horizontal advection was weak throughout the investigation period. The time series station corresponded to the permanent DYFAMED station (JGOFS-France, Buat-Ménard and Lambert, 1993).

The vertical distribution of cyanobacteria as well as of pico- and nanophytoplankton populations were studied through flow cytometric analyses. As a consequence of the expected role of DVM, the study was undertaken at the time scale of a few hours to account for the effect of this repetitive phenomenon with a good enough resolution.

\section{MATERIALS AND METHODS}

\section{Sampling site, schedule and general features}

The DYNAPROC cruise (DYNAmics of rapid PROCesses in the water column) was conducted on board R.V. Le Suroit and R.V. Téthys-II during May 1995 in the open Ligurian Sea (northwestern Mediterranean). Most of the measurements were performed at a time series station $\left(43^{\circ} 25.2 \mathrm{~N}, 7^{\circ} 51.8\right.$ E; 28 milles offshore), further referred as TSS (Fig. 1). From several types of observations, such as ADCP (Acoustic Doppler Current Profiler) records and CTD casts along a transect from the coast to the TSS and on a 16-station grid centered on the TSS (Fig. 1), it could be stated that horizontal advection at the TSS remained weak throughout the observational period (Andersen and Prieur, 2000). The changes in the observed parameters of the water col-

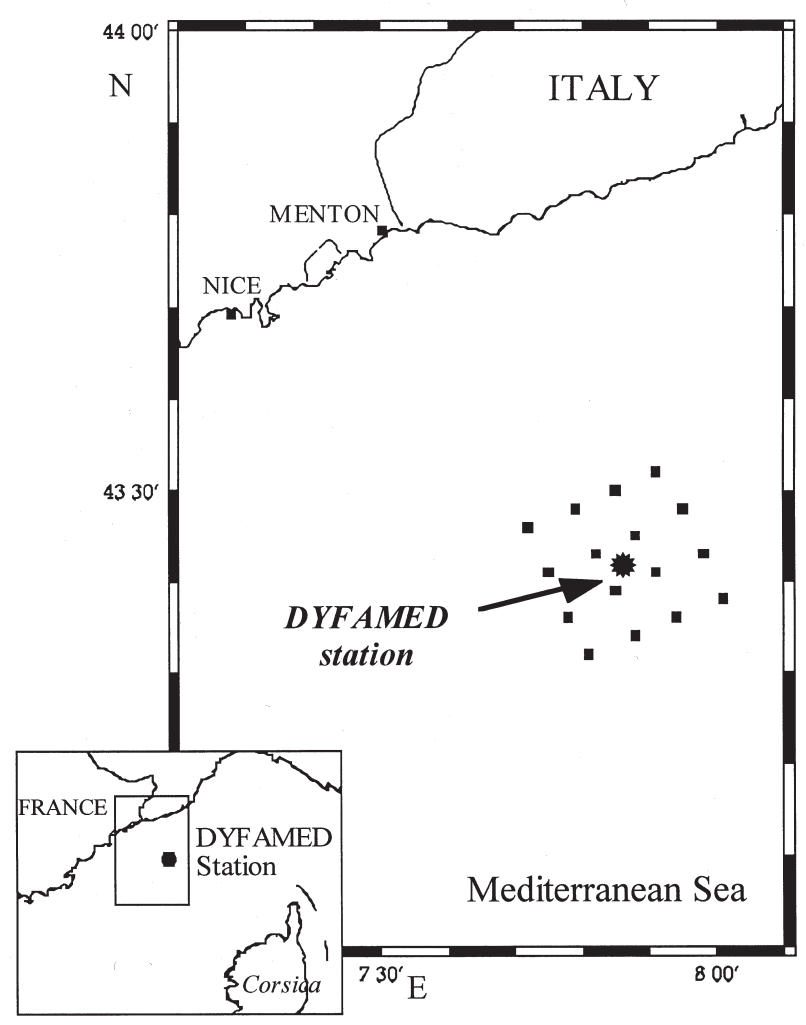

FIG. 1. - Location of the investigated site in the northwestern Mediterranean Sea. (H ) position of the time series station (TSS). (6) grid of 16 stations.

umn would have therefore involved redistribution of properties in the water column rather than the effect of horizontal advection events. The CTD was implemented with an oxygen sensor and a fluorometer.

The cruise was divided into four legs. The present study deals only with leg 2 (10 - 16 May) where the different samplings for flow cytometric analyses were achieved at the TSS or within less than one nautical mile from it. This leg focused on the characterization of autotrophic and heterotrophic processes which can influence the vertical flux of matter on short-time scales. During the period of concern (leg 2), time (UTC) of sunrise varied from $0415 \mathrm{~h}$ to $0410 \mathrm{~h}$; that of sunset from $1841 \mathrm{~h}$ to $1845 \mathrm{~h}$.

\section{Flow cytometry and phytoplankton biomass estimation}

Single cell analysis (see Demers, 1990, and references herein) was run with the CYTORON ABSOLUTE (ORTHO Diagnostic Systems) flow cytometer, with a laser excitation wavelength at 488 $\mathrm{nm}$, characterizing each cell by five optical parameters: two diffraction parameters, forward and right 
angle scatter, three fluorescence parameters related to emissions in the red $(>620 \mathrm{~nm})$, orange (565-592 $\mathrm{nm})$ and green $(515-530 \mathrm{~nm})$ wavelength ranges. Variations in counting with the CYTORON ABSOLUTE varied by less than $3.7 \%(\mathrm{SD}, \mathrm{n}=23)$ over a range of concentrations extending one order of magnitude. The dates and times (UTC) of the reported samplings are given in Figure legends. Prefiltered (on $100 \mu \mathrm{m}$ mesh size net) samples were fixed with 2\% paraformaldehyde (Trousselier et al., 1995; see also Vaulot et al., 1989) and stored in liquid nitrogen up to analysis. Just before analysis, samples were rapidly thawed in a $30^{\circ} \mathrm{C}$ water bath and fluorescent beads of $10 \mu \mathrm{m}$ in diameter were added in order to normalize the flow cytometer setting and to provide a reference for concentration calculations. Data were collected and stored in listmode with the IMMUNOCOUNT software (ORTHO Diagnostic Systems). Cluster analyses were run with the WINLIST software (VERITY Software House Inc.). The flow cytometric analysis was restricted to $<10 \mu \mathrm{m}$ phytoplanktonic cells. Four groups were resolved on the basis of the five optical parameters characterizing each cell and identified as prochlorophytes, cyanobacteria, pico- and nanoeukaryotes (Li, 1994). Cyanobacteria biomasses have been expressed in terms of carbon by using the estimation of $250 \mathrm{fg} \mathrm{C}$ cell $^{-1}$ (Kana and Glibert, 1987a,b; Campbell et al., 1994).

\section{Macroplankton and micronekton}

A series of oblique hauls was performed in the vicinity of TSS in the 0-1000 m water column. Zooplankton samples were taken with a multiple opening and closing net, the Bioness (Sameoto et al.,
1980), equipped with $500 \mu \mathrm{m}$ mesh nets of a mouth area of $1 \mathrm{~m}^{2}$. For the purpose of this paper, we only consider the upper three strata sampled (250-150, 150-75 and 75-0 m), and the macroplankton and micronekton species or taxonomic groups. Detailed results are presented in Andersen et al. (submitted). Average day and night densities in the 0-250 m water column (ind. $\mathrm{m}^{-2}$ ) were calculated for each species or group by combining the results of the four midday hauls or the two midnight hauls performed during the process legs (legs 2 and 4, 10-16 May, 26 May-1 June).

\section{RESULTS}

During the reported observational period (10-13 May), hydrological conditions were relatively stable with a maximum fluorescence located at $30 \mathrm{~m}$ and a thermocline at about $10 \mathrm{~m}$ (Fig. 2).

The flow cytometric analysis of phytoplanktonic cells along vertical profiles revealed that cyanobacteria were largely the dominant population in terms of cell concentration (Fig. 3). The cyanobacteria, prochlorophytes and large eukaryotes (tentatively identified as nanoflagellates) exhibited a well defined peak in cell numbers at $30 \mathrm{~m}$ depth (Fig. 3), before the upward vertical migration. A sharp decrease was observed down to $50 \mathrm{~m}$, reaching the zero level at 75-100 m depth.

The cyanobacteria vertical distribution in the upper $200 \mathrm{~m}$ was also monitored over a $36 \mathrm{~h}$ cycle with a $4 \mathrm{~h}$ frequency. Figure 4 shows the time variation of the cyanobacteria vertical distribution through this cycle. During day-time, both on 11 and 12 May, cyanobacteria were largely grazed at $20 \mathrm{~m}$,
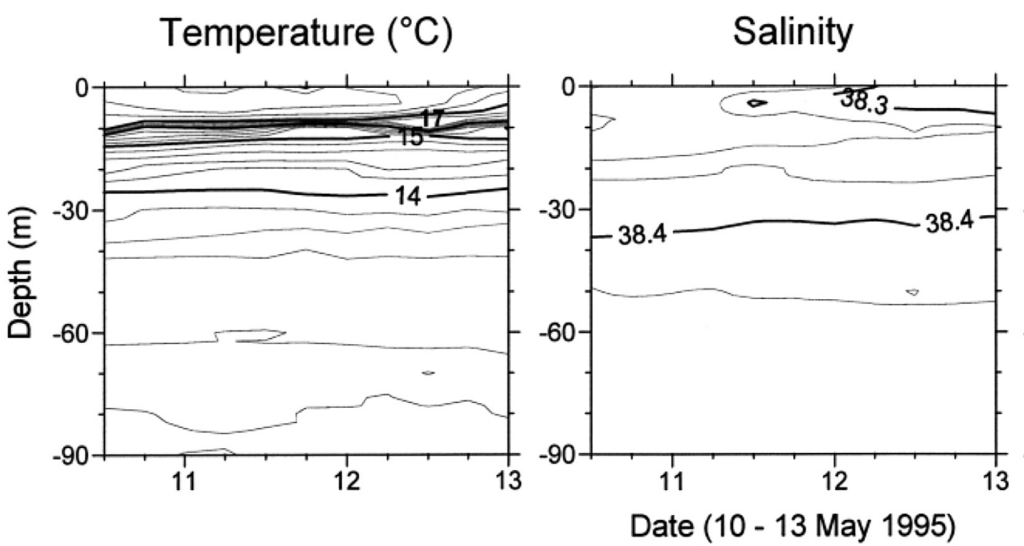

Chlorophyll a $\left(\mathrm{mg} \mathrm{m}^{-3}\right)$

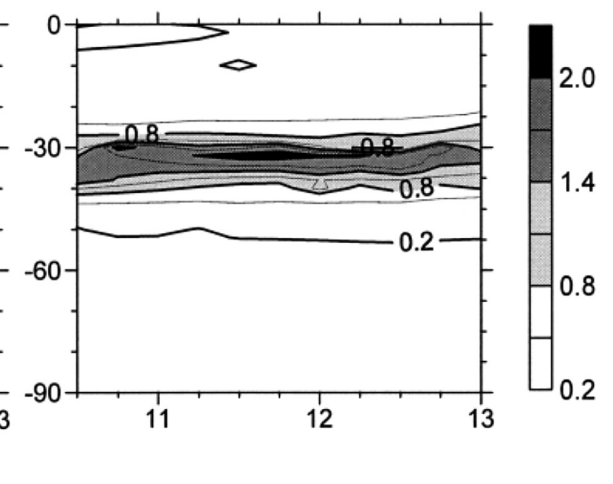

FIG. 2. - Time-depth distributions of potential temperature, salinity and chlorophyll $a$ in the 0-90 m water column at the Time Series Station (TSS) between 10 and 13 May. The graphs are derived from 18 CTD casts performed during this period (adapted from Andersen and Prieur, 2000 ). Isolines are drawn at 0.2 intervals for temperature, 0.025 intervals for salinity and 0.3 intervals for chlorophyll. 

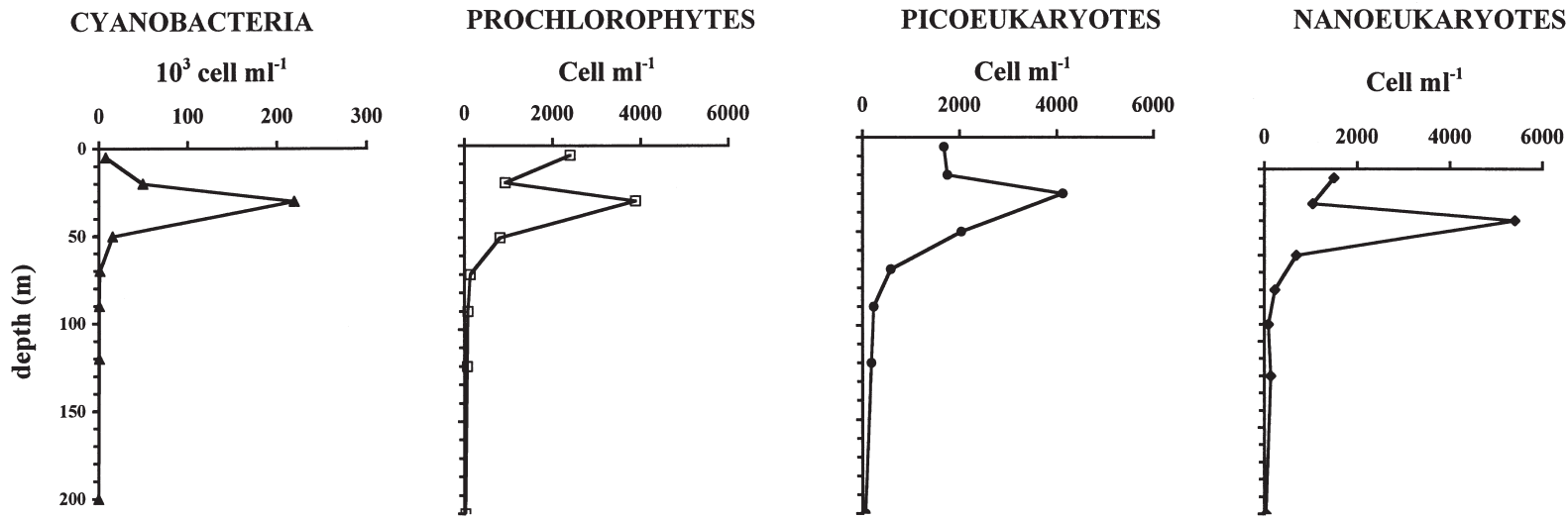

FIG. 3. - Vertical distribution of phytoplankton belonging to the size fraction $<10 \mu \mathrm{m}$. Different scales of cell concentration have been used to account for differences in abundance of the 4 resolved populations. Samples were collected on 10 May at $1500 \mathrm{~h}$ from the N.O. Téthys II.
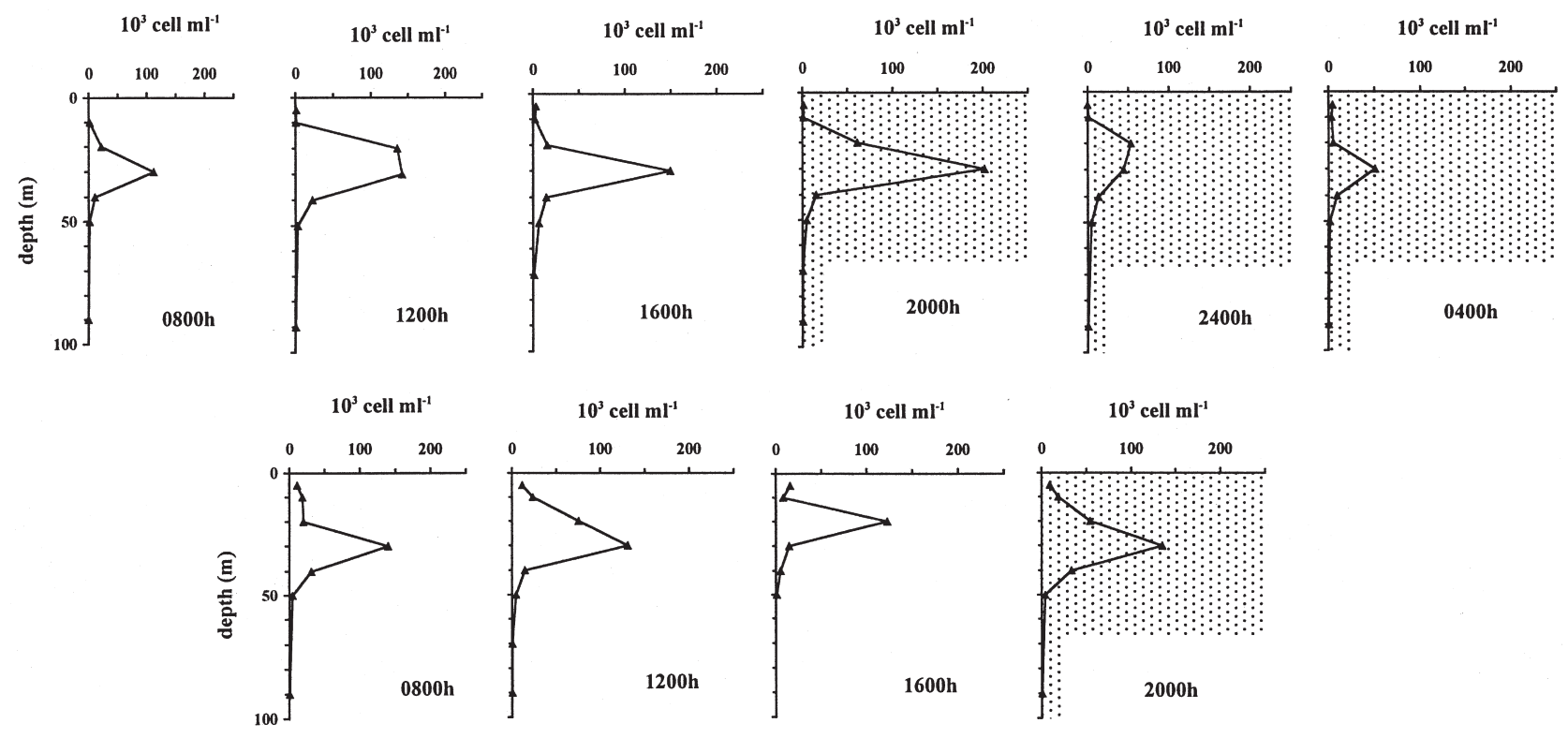

FIG. 4. - Time course of the vertical distribution of cyanobacteria over the $36 \mathrm{~h}$ cycle with a $4 \mathrm{~h}$ sampling frequency. The profile samples were collected from the N.O. Suroit on 11 an 12 May.

but not deeper. At $20 \mathrm{~m}$ depth, the cyanobacteria concentration dropped by $89 \%$ between 1200 and 1600h both on 11 and 12 May (Fig. 4). At the end of the next interval, the population recovered to a level of 55 and $72 \%$ of the abundance at $1200 \mathrm{~h}$ on 11 and 12 May respectively. In contrast, at $30 \mathrm{~m}$ depth, the cyanobacteria concentration exhibited an increase of $5 \%$ on 11 May and a decrease of $6 \%$ on 12 May and further increased during the next interval by 35 and $10 \%$ respectively.

The cell concentration reached a maximum at $2000 \mathrm{~h}$ at $30 \mathrm{~m}$ depth. The cyanobacteria population then decreased to reach a minimum 8 hours later. It is important to note that between $2000 \mathrm{~h}$ and $2400 \mathrm{~h}$, the cyanobacteria concentration at $30 \mathrm{~m}$ depth dropped by $79 \%$ whereas it remained stable at $20 \mathrm{~m}$. In contrast, in the course of the next 4 hours, the cyanobacteria concentration at $30 \mathrm{~m}$ remained stable, but the one at $20 \mathrm{~m}$ depth dropped to almost zero (90\% decrease).

The temporal variation of cyanobacteria concentration integrated over the upper $90 \mathrm{~m}$ is displayed in Figure 5. The integrated cell content seems to oscillate around a mean value, of about $210^{12}$ cell m-2. The cell reduction at night amounts to $2.1310^{12}$ cell $\mathrm{m}^{-2}$. The integrated chl $a$ concentration did not exhibit parallel variations (not shown).

The rate of abundance variation $\left(\tau, h^{-1}\right)$ of the cyanobateria has been calculated like a division rate $(\mu)$ for each time interval of the integrated concen- 


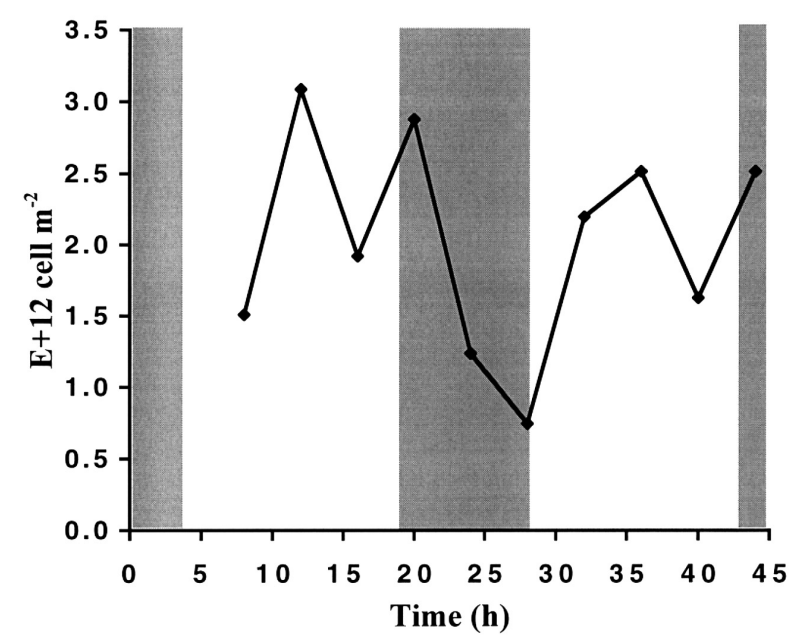

FIG. 5. - Variation of the cyanobacteria concentration integrated over the 0-90 $\mathrm{m}$ upper layer during the $36 \mathrm{~h}$ cycle.

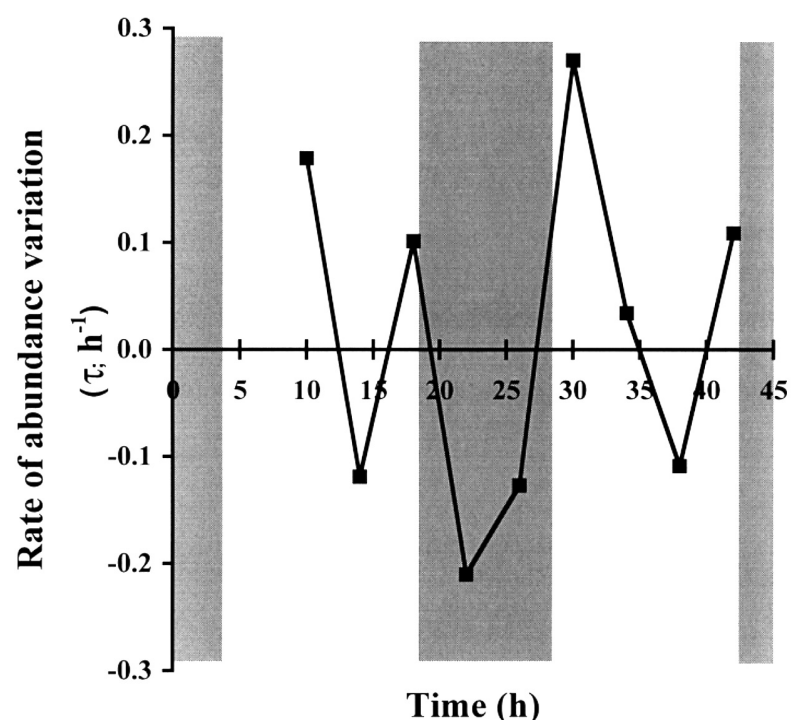

FIG. 6. - Rate of variation $\left(\tau, \mathrm{h}^{-1}\right)$ of the cyanobacteria abundance integrated over the 0-90 m upper layer during the $36 \mathrm{~h}$ cycle. Negative values mean that predation overruled cell division during the referred interval. The abscisses of data points correspond to the midpoints of the time intervals for which $\tau$ is calculated.

trations shown in Figure 5. The amplitude of these variations is illustrated in Figure 6. The largest changes of $\tau$ observed during the reported cycle $\left(-0.21\right.$ to $\left.0.27 \mathrm{~h}^{-1}\right)$ occurred during night-time. Losses in cyanobacteria during one period appeared to be rapidly compensated in the following ones.

The integrated losses of cyanobacteria over the $90 \mathrm{~m}$ upper water column during the night (from $2000 \mathrm{~h}$ to $0400 \mathrm{~h}$ ) amount to $534 \mathrm{mg} \mathrm{C} \mathrm{m}^{-2}$, which is of the same order as the primary production (497 $\mathrm{mg} \mathrm{C} \mathrm{m}^{-2}$ ) determined on 11 May (Vidussi et al., 2000).

\section{Diel vertical migrations}

Average total number of individuals per square metre for the 0-250 $\mathrm{m}$ water column was determined for the macroplankton and micronekton individuals of size $>5 \mathrm{~mm}$. About $96 \%$ of the total number, day and night results combined, were represented by four groups: the euphausiids and the siphonophores (32$35 \%$ each), and the pteropods and hyperiid amphipods (14-15\% each). The pteropod group was almost exclusively composed of two thecosome species, Cavolinia inflexa ( 94\%) and Clio pyramidata $(\sim 5 \%)$. Night catches in the upper $250 \mathrm{~m}$ were significantly higher than day catches (t-test), with a ratio night/day of 3.1-4.9 for siphonophores and euphausiids, of 12 for amphipods and up to 30 for pteropods. This suggests that most of these organisms migrated at night and concentrated in the upper layers.

\section{DISCUSSION}

In terms of cell concentration, cyanobacteria were the dominant population, in contrast with the reported dominance of prochlorophytes in oligotrophic areas of the Atlantic (Chisholm et al., 1988; Olson et al., 1990) and Pacific Ocean (Campbell et al., 1994). The dominance of cyanobacteria over prochlorophytes is in agreement with other observations in the Mediterranean Sea (Vaulot and Partensky, 1991; Vaulot et al., 1990; Martin, 1997). Due to the low level of prochlorophyte abundance, the pigment zeaxanthin can be considered as representative of the cyanobacteria population. The pigment analysis (Vidussi et al., 2000) indicated that the contribution of cyanobacteria to the overall chlorophyll $a$ concentration amounted to only 11-12\% during the reported experiment, which may explain why cyanobacteria abundance and chlorophyll $a$ concentration do not vary in parallel. Heterotrophic nanoflagellates are known to feed on cyanobacteria. In a parallel investigation during the DYNAPROC cruise (Pérez et al., 2000), ciliates were shown to be most present at the level of maximum fluorescence during day time. They are likely to have contributed to the grazing of cyanobacteria during that period, which is supported by a positive relationship between depth integrated values of their abundance and zeaxanthin concentration (Pérez et al., 2000). Cyanobacteria predation by ciliates was expected from the food ration of ciliates reported by Rassoulzadegan et al. (1988). The grazing of cyanobacteria at night was larger than during 
day time. In contrast, dinoflagellates would undergo a downward migration at night (Blasco, 1978; Passow, 1991; Vaqué, personal communication for the western Mediterranean) whereas part of the population of heterotrophic ciliates migrated from the $20-30 \mathrm{~m}$ depth to the surface (Pérez et al., 2000). This enhanced predation occurring when a significant fraction of the day time predators has left the level occupied by cyanobacteria, strongly suggests that they were the prey, to some extent, of daily migrant planktonic species. Indeed, the DVM study supports the invasion of the upper $250 \mathrm{~m}$ at night by the migrant organisms, consistently with earlier observations at the DYFAMED station by Andersen and Sardou (1992) in May 90, and by Sardou and Andersen (1993) in April 91. Among these migrant organisms, the thecosome pteropods, swarming in the surface layer at night, would shortcut the usual food web by feeding directly on particles as small as $1 \mu \mathrm{m}$ bacteria (Gilmer, 1990). In fact, thecosome pteropods, such as those observed during the DYNAPROC cruise, use large external mucous webs to collect and ingest small food items. Consequently, the related fraction of the loss of cyanobacteria biomass $\left(534 \mathrm{mg} \mathrm{C} \mathrm{m}^{-2}\right)$ observed at night represents a potentially exported biomass which should be accounted for when calculating carbon budgets. Such budgets should also include grazed heterotrophs that were not considered in the present estimation.

\section{ACKNOWLEDGEMENTS}

The present work was part of the cruise DYNAPROC; it was supported by the CNRS-INSU, DYFAMED programme (France-JGOFS) and the GEODYME programme (contract $\mathrm{N}^{\circ} 930061$ of the MTP-MAST II programme). We thank the captains and crews of the N.O. Téthys II and N.O. Suroit for their efficient assistance at sea and C. DescolasGros, chief scientist on the Téthys II, for her intensive involvement and stimulating support. We are also grateful to S. Belviso for kindly collecting samples for flow cytometric analyses.

\section{REFERENCES}

Andersen, V. and J. Sardou. - 1992. The diel migrations and vertical distributions of zooplankton and micronekton in the Northwestern Mediterranean Sea. 1. Euphausiids, mysids, decapods and fishes. J. Plankton Res., 14 : 1129-1554.

Andersen, V. and L. Prieur. - 2000. One-month study in the open NW Mediterranean Sea (DYNAPROC experiment, May 1995):
Overview of hydrobiogeochemical structures and effects of wind events. Deep-Sea Res. I, 47: 397-422.

Andersen V., Gubanova A., Nival P. and Ruellet T. - (submitted). Zooplankton community during the transition from spring bloom to oligotrophy in the open NW Mediterranean and effects of wind events. 2 - Vertical distributions and migrations. J. Plankton Res.

Angel, M.V. - 1989. Does mesopelagic biology affect the vertical flux? In: W.H. Berger, V. S. Smetacek and G. Wefer, (eds.) Productivity of the Ocean: Present and Past. pp. 155-173. John Wiley \& Sons Limited.

Bishop, J.K.B. - 1989. Regional extreme in particulate matter composition and flux: effects on the chemistry of the ocean interior. In: W.H. Berger, V. S. Smetacek and G. Wefer, (eds.), Productivity of the Ocean: Present and Past. pp. 117-137. John Wiley \& Sons Limited.

Blasco, D. - 1978. Observations on the diel migration of marine dinoflagellates off the Baja California Coast. Mar. Biol., 46: 41-47.

Buat-Ménard, P. and C.E. Lambert. - 1993. Overview of the DYFAMED program. Ann. Instit. Océanogr. Paris, 69: 101105 .

Campbell, L., H.A. Nolla and D. Vaulot. - 1994. The importance of Prochloroccocus to community structure in the central North Pacific Ocean. Limnol. Oceanogr., 39: 954-961.

Carlson, C.A., H.W. Ducklow and A.F. Michaels. - 1994. Annual flux of dissolved organic carbon from the euphotic zone in the northwestern Sargasso Sea. Nature 371: 405-408.

Chisholm, S.W., R.J. Olson, E.R. Zettler, R. Goericke, J.B. Waterbury and N.A. Welschmeyer. - 1988. A novel free-living prochlorophyte abundant in the oceanic euphotic zone. Nature, 334: 340-343.

Copin-Montégut, G. and B. Avril. - 1993. Vertical distribution and temporal variation of dissolved organic carbon in the NorthWestern Mediterranean Sea. Deep-Sea Res. 40: 1963-1972.

Demers, S. - 1990. Particle analysis in oceanography. NATO ASI Series G, Ecological Sciences, Vol. 27, 416 p. Springer Verlag Berlin, Heidelberg.

Dugdale, R.C. and J.J. Goering. - 1967. Uptake of new and regenerated forms of nitrogen in primary productivity. Limnol. Oceanogr., 12: 196-206

Eppley, R.W. and B.J. Peterson. - 1979. Particulate organic matter flux and planktonic new production in the deep ocean. Nature, 282: 677-680.

Gilmer, R.W. - 1990. In situ observations of feeding behavior of thecosome pteropod molluscs. Am. Malacol. Bull., 8: 53-59.

Kana, T.M. and P.M. Glibert. - 1987a. Effect of irradiances up to $2000 \mathrm{mE} \mathrm{m}^{-2} \mathrm{~s}^{-1}$ on marine Synechococcus WH7803-I. Growth, pigmentation, and cell composition. Deep-Sea Res., 34: 479495.

Kana, T.M. and P.M. Glibert. - 1987b. Effect of irradiances up to $2000 \mathrm{mE} \mathrm{m}^{-2} \mathrm{~s}^{-1}$ on marine Synechococcus WH7803-II. Photosynthetic responses and mechanisms. Deep-Sea Res., 34: 497516.

Lampitt, R.S., W.R. Hillier and P.G. Challenor. - 1993. Seasonal and diel variation in the open ocean concentration of marine snow aggregates. Nature, $362: 737-739$.

Li, W.K.W. - 1994. Primary production of prochlorophytes, cyanobacteria, and eukaryotic ultraphytoplankton: measurements from flow cytometric sorting. Limnol. Oceanogr., 39: $169-175$.

Longhurst, A.R. and W.G. Harrison. - 1989. The biological pump: profiles of plankton production and consumption in the upper ocean. Progr. Oceanogr., 22: 47-123.

Martin, V. - 1997. Etude par cytométrie en flux de la distribution des populations phytoplanctoniques en Méditerranée. Mise en relation avec la production métabolique de $\mathrm{CO}_{2}$ et comparaison avec le Golfe du Saint Laurent. Thesis, Univ. Méditerranée.

Olson, R.J., S.W. Chisholm, E.R. Zettler, M.A. Altabet and J.A. Dusenberry. - 1990. Spatial and temporal distribution of prochlorophyte picoplankton in the North Atlantic Ocean. Deep-Sea Res., 37: 1033-1051.

Passow, U. - 1991. Vertical migration of Gonyaulax catenata and Mesodinium rubrum. Mar. Biol., 110: 455-463.

Pérez, M.T., J.R. Dolan, F. Vidussi and E. Fukai. - 2000. Diel vertical distribution of planktonic ciliates within the surface layer of the NW Mediterranean (May 1995). Deep-Sea Res. I, 47: 479-503. 
Pujo-Pay, M. - 1995. L'azote et le phosphore en milieu marin. Importance des formes organiques en milieu océanique du large. Thesis, Univ. Méditerranée. 164 pp.

Rassoulzadegan, F., M. Laval-Peuto and R.W. Sheldon. - 1988 Partitioning of the food ration of marine ciliates between picoand nanoplankton. Hydrobiologia, 159: 75-88

Sameoto, D.D., L.O. Jaroszynski and W.B. Fraser. - 1980. BIONESS, a new design in multiple net zooplankton samplers. J. Fish. Res. Board Can., 37: 722-724.

Sardou, J. and V. Andersen. - 1993. Micronecton et macroplancton en mer Ligure (Méditerranée): migrations nycthémérales et distributions verticales. Oceanol. Acta, 16: 381-392.

Smith, D.C., M. Simon, A.L. Alldredge and F. Azam. - 1992. Intense hydrolytic enzyme activity on marine aggregates and implications for rapid particle dissolution. Nature, 359: 139-142.

Trousselier, M., C. Courties and S. Zettlemaier. - 1995. Flow cytometric analysis of coastal lagoon bacterioplancton and picoplancton: fixation and storage effects. Est. Coast. Shelf Res., 40: 621-623.

Vaulot, D, C. Courties and F. Partensky. - 1989. A simple method to preserve oceanic phytoplankton for flow cytometric analyses. Cytometry, 10: 629-635.

Vaulot, D., F. Partensky, J. Neveux, R.F.C. Mantoura and C. Llewellyn. - 1990. Winter presence of prochlorophytes in surface waters of the northwestern Mediterranean Sea. Limnol. Oceanogr., 35: 1156-1164.

Vaulot, D. and F. Partensky. - 1991. Photosynthetic picoplankton of the northwest Mediterranean Sea in summer: comparison with the winter situation. Water Poll. Res. Rep., 28: 173-181.

Vidussi, F., J.-C. Marty and J. Chiavérini. - 2000. Phytoplankton pigment variations during the transition from spring bloom to oligotrophy in the northwestern Mediterranean Sea. Deep-Sea Res. I, 47: 423-445 